2003

\title{
The Impacts of Walter Isard on Geography
}

Randall Jackson

West Virginia University, randall.jackson@mail.wvu.edu

Follow this and additional works at: https://researchrepository.wvu.edu/rri_pubs

Part of the Regional Economics Commons

\section{Digital Commons Citation}

Jackson, Randall, "The Impacts of Walter Isard on Geography" (2003). Regional Research Institute Publications and Working Papers. 130. https://researchrepository.wvu.edu/rri_pubs/130 


\title{
The impacts of Walter Isard on geography
}

\author{
Randall W. Jackson \\ Director, Regional Research Institute, West Virginia University, Morgantown, \\ WV 26506-6825, USA \\ (e-mail: Randall.Jackson@mail.wvu.edu)
}

\begin{abstract}
In the course of preparing this paper, which initially focused solely on identifying the impacts of input-output analysis on geography, a much broader perspective on the impacts of Walter Isard on geography ultimately emerged. In the tradition of input-output analysis, these impacts are grouped into direct, indirect, and induced effects, and summarized under the heading of influence. Walter Isard touched the lives of many through personal relationships, books and articles, and an energetic devotion to and enthusiasm for the creation of a regional science association. The Regional Science Association and its publications supported something of a greenhouse environment in which the seedlings of GIS and scientific geography could take root, until they were well enough established to enter mainstream geography. While clearly not limited to geography, the fruits of Walter Isard's labors continue to populate the discipline through his contemporaries, their students, students' students, and so on. The formative years of both regional science and scientific geography left an indelible mark on the nature of geographic inquiry.
\end{abstract}

Key words: Walter Isard, Geography, Input-Output

JEL classification: C67, N01, R15

\section{Introduction}

When first asked to prepare and contribute an article for this journal, to be included in an issue celebrating Walter Isard and fifty years of the Regional Science Association, I was eager to participate. My topic was to be the impact of the input-output framework on geography. As a geographer for whom both the input-output framework and impact assessments have been near and dear, I set out with some considerable enthusiasm. Along the way, however, the path took some interesting turns, and I learned much about an era of great significance to both geography and regional science. 
I also discovered something of the magnitude of the historian's challenge in constructing an accurate depiction of historical events! As the tracing on influence naturally progresses backward in time, my attention was drawn quickly to the early days of regional science, when both regional science and quantitative, or scientific geography, were in their infancies. Anyone with such an opportunity will find it challenging to reconcile not only different but sometimes contradictory descriptions of times, places, and events. Historical inaccuracies and omissions are regrettable but likely inevitable, and for any contained herein, I sincerely apologize. Nevertheless, I am deeply indebted and grateful to all of those with whom I corresponded in preparing this paper.

One personally discouraging conclusion drawn early along the path is that the impacts on geography of the input-output frameworks, per se, have been somewhat less far-reaching than I had imagined. In due course, I will address these impacts explicitly. In reaching that conclusion, however, a much more substantial impact on geography crystallized, and I will take the liberty also to address explicitly the broader influence Walter Isard exerted on geography.

Generally, and unapologetically drawing on the input-output impacts assessment terminology, Walter's impacts on geography have been direct, indirect, and induced. The direct impacts are the results of professional and personal contributions; the indirect impacts are the effects of a) the formation of the Regional Science Association, b) Location and SpaceEconomy and Methods of Regional Analysis; and the induced impacts are, in effect, second round institutional consequences.

\section{Input-output and direct effects}

One of the methods most strongly identified with Walter Isard during the first decade was regional input-output analysis. As such, it is logical to begin by tracing perhaps the most easily identifiable of all direct effects on geography: the impacts of input-output analysis. As hinted above, however, this tracing draws a path that is not especially overwhelming.

Although a number of geographers already had been exposed to regional input-output analysis from Isard's other publications, the appearance of Methods in 1960 solidified its position in the methodological tool kit of the regional analyst. Despite the exposure it provided, however, few geographers adopted the approach to the extent of basing primary research and publication paths on an input-output foundation. Morgan Thomas (Washington) exposed many students to input-output, including John Parr, William Beyers, Gunther Krumme, Geoffrey Hewings, Rodney Erickson, and others. ${ }^{1}$ Of these, Hewings, who was more strongly influenced by Charles Tiebout, formed input-output into the centerpiece of his research career, and continues to publish prolifically in the area today. Hewings also has advised a large number of students of input-output, not only nationally and internationally, but across disciplines as well. His Ph.D. advisees have

\footnotetext{
${ }^{1}$ Another individual with ties to University of Washington geography is Dick Conway, who, while a geographer, went into private consulting.
} 
studied not only in geography, but in economics, planning, and other related disciplines.

Nevertheless, although input-output research and instruction has been continued within geography, relatively few geographers adopted inputoutput as a stronghold for research, and those who have done so have maintained those emphases for varying durations. The names include Breandan O'hUallachain, Randall Jackson, Sarwar Jahan, Adrian Esparza, Harrison Campbell, Federico Cuello, Jungyul Sohn, and Nuzul Achjar. Although their work may not all center on input-output, the threads of the framework can be seen often to continue through their publications.

Naturally, these individuals have also advised varying numbers of students, but it is safe to say that they have produced a number of inputoutput oriented Ph.D.s that is smaller than the group above. While it need not have been the case, and while it does not seem to hold internationally or outside of geography, it seems that each round of input-output impacts within US geography is indeed smaller than the preceding round.

\section{Indirect effects}

\subsection{The regional science association ( $R S A)$}

In communication, Marble writes, "Perhaps his greatest impact came not as an individual, but through the establishment of the Regional Science Association. This encouraged a number of geographers at a time when their own journals were not accessible to modeling or quantitative approaches,", and at a time when venues for meeting and exchanging ideas with likeminded individuals were severely limited. These like-minded geographers are strongly associated with the quantitative revolution in geography, which was transpiring coincidentally with the founding and development of regional science and the Regional Science Association. The group includes such names as Duane Marble, Brian Berry, Richard Morrill, William Garrison, Waldo Tobler, Julian Wolpert, Arthur Getis, Stephen Gale, Maurice Yeates, William Bunge, Barry Garner, Michael Dacey, Edward Taaffe, Edward Ullman, Morgan Thomas, William Clark, John Nystuen, William Warntz, and others to whom apologies are extended. Of these, many published papers in early volumes of the Papers of the Regional Science Association, and still more participated at annual meetings. ${ }^{3}$

Of the forty papers and commentaries published by geographers (i.e., individuals I was able to identify as geographers) in the PRS during the RSA's first ten years, less than a handful actually cited any of Walter Isard's

\footnotetext{
${ }^{2}$ I exchanged communications with a number of these individuals, but have opted in some cases not to include direct quotes. Where quotes are provided, I have simply referred to the source by last name. However, I will at times borrow liberally from those communications, as they provide much of the basis for this report. I am very grateful to, and for the insights of those who corresponded, as I am grateful, for that matter, to the entire group, which provided the foundation upon which my own career has been based!

${ }^{3}$ Since the Papers of the Regional Science Association had various names during the first ten years, I will refer to it only as the PRS.
} 
works. Many of these publications (listed in References for those interested) focused on areas of research complimentary to those that attracted Walter's focus, such as urban and transport geography, and spatial interaction, and as such, required no direct reference to Isard. Yet all of these geographers benefited from the Association. "The formation of the Regional Science Association in 1954 was an important step, offering geographers broad multidisciplinary support for their drive towards science... The RSA meetings were an important place to gather and feel a sense of self-worth, something that was certainly not present in AAG meetings at the time rather the atmosphere there was one of hostility and denigration" (Berry). Others confirmed that regional science offered both intellectual and personal contacts.

The RSA also played a particularly important role as an alternate professional association for those with quantitative (socio-) economic geography and modeling interests beginning again in the early 1980s (and continuing to some extent still) when a succession of anti-quantitative isms swept through the discipline. The Regional Science Association has seen varying degrees of participation from geographers over the years. For many geographers, the RSA continues to be more important than the Association of American Geographers in terms of both publication outlets and the exchange of research ideas with colleagues at conferences.

\subsection{The books}

Although his interests and ways of working and thinking were already on a maturing path before intersecting Isard's path, William Garrison (at Washington) immediately adopted Isard's Location and Space-Economy (1956) as a partial text for his advanced economic geography course. Thus began a broad exposure to geographers of the day. Although Location was read by nearly everyone, most agreed that Methods of Regional Analysis (1960) had more impact since it contained more "useful ideas and tools." While many noted equally important influences of the era for geographers (such as Christaller and Lösch, as well as Hagerstrand), nearly every communication received pointed to the significance of the introduction of these two books, and their influence on geography generally.

Walter Isard has been a prolific author. Focusing on these first two books is in no way intended to detract from the significance of his many other papers, proceedings, and books. These simply are the two publications that were cited by correspondents as influential publications during the early years.

\section{Induced impacts}

Although the geography department at the University of Illinois changed its name to Geography and Regional Science, and despite the establishment of a department of Regional Science at the University of Pennsylvania, the most profound "induced" impacts may well be reflected in the Geography and Regional Science Program at the National Science Foundation. "The early 
NSF directorate was nearly exclusively a center for regional science activity" (Getis). Several of its leaders were strongly influenced by, and have been supporters of regional science. These include such Directors as Brian Holly, JW Harrington, Thomas Leinbach, and especially Barry Moriarty, whose influence was particularly apparent. More recently, the regional science "emphasis has become estranged from geography as the discipline moves in the directions of GIS and post-modernism" (Getis). "So for the last 25 years, the influence of regional science occurs instead through the specialized networks in specific topic areas; e.g., urban models, transportation, population and migration, etc" (Morrill).

\section{Influence}

As noted in correspondence, influence is a tricky concept. Developments in both geography and regional science were as rapid during the 1950s and 1960s as ever before or since. It would be difficult to deny that geography and regional science have influenced one another. Yet there is no doubt that the RSA and the PRS provided vitally important outlets for geographers at a critical time in the history of geography, and there is no doubt that without Walter Isard, neither the RSA nor the PRS would have happened.

Influence is often measured by citations, but in this case, an analysis based on Isard citations alone would be painstaking, and adding indirect influences to the analysis with names such as Garrison, Berry, Marble, Getis, Morrill, Tobler, Wolpert and the rest would render the task nearly impossible. Suffice it to say that Walter's influence extends both directly and indirectly, and to varying degrees, to nearly every corner of scientific human geography and GIS.

Walter Isard's contribution to geography has long been formally recognized and appreciated. He received the Honors Award from Association of American Geographers 1981, and was named a Fellow of the American Geographic Society in 1984. And it was geographers, much more than economists, who were instrumental in getting him elected to the National Academy of Sciences.

Lines of geographic inquiry that can be traced directly to Walter Isard are few. Yet his presence and activities during a critical period in the history of geographic thought clearly accelerated the process of change. A dynamic and endlessly energetic individual, all with whom I corresponded expressed high regard for Walter Isard, and their pleasure upon learning of this issue in his honor. Reflecting well the thoughts and comments of others, Garrison writes, "Walter Isard is a very ethical person who has worked hard, driven by his intellectual convictions. He has certainly made his students and others lives better. Good for him." And good for geography.

\section{References}

Berry BJL (1959) Discussion: Ecological analysis of regions. Papers and Proceedings of the Regional Science Association 5:133-135

Berry BJL (1960) An inductive approach to the regionalization of economic development. Papers and Proceedings of the Regional Science Association 6:83-84 
Berry BJL (1964) Cities as systems within systems of cities. Papers of the Regional Science Association 13:147-163

Boyce RR, Clark WAV (1963) Selected spatial variables and central business district retail sales. Papers and Proceedings of the Regional Science Association 11:167-193

Bramhall DF (1961) Projecting regional accounts and industrial locations:Reflections on policy applications. Papers and Proceedings of the Regional Science Association 7:89-118

Dacey MF (1964) Two-dimensional random point patterns: A review and an interpretation. Papers of the Regional Science Association 13:41-55

Dziewonski K (1962) Theoretical problems in the development of economic regions (with special emphasis on Poland). Papers of the Regional Science Association, European Congress, The Hague 8:43-54

Dziewonski K (1962) Theoretical problems in the development of economic regions (within one country)-II. Papers of the Regional Science Association, European Congress, Zurich 10:51-60

Garrison WL (1955) The spatial impact of transport media - studies of rural roads. Papers and Proceedings of the Regional Science Association 211-225

Garrison WL (1956) Estimates of the parameters of spatial interaction. Papers and Proceedings of the Regional Science Association 2:280-288

Garrison WL (1960) Connectivity of the interstate highway system. Papers and Proceedings of the Regional Science Association 6:121-137

Garrison WL (1964) Values of regional science. Papers of the Regional Science Association 13:711

Garrison WL, Marble DF (1964) Factor-analytic study of the connectivity of a transportation network. Papers of the Regional Science Association, European Congress, Lund 12:231-238

Isard W (1956) Location and Space-Economy. Cambridge, Massachusetts, The M.I.T. Press

Isard W (1960) Methods of Regional Analysis:An Introduction to Regional Science. Cambridge, Massachusetts, The M.I.T. Press

James PE (1958) Discussion:The core and boundaries of regional science. Papers and Proceedings of the Regional Science Association 4:23-26

Kates RW (1963) Perceptual regions and regional perception in flood plain management. Papers and Proceedings of the Regional Science Association 11:217-227

Marble DF (1959) Transport inputs at urban residential sites. Papers and Proceedings of the Regional Science Association 5:253-266

Marble DF, Nystuen JD (1963) An approach to the direct measurement of community mean information fields. Papers and Proceedings of the Regional Science Association 11:99-109

Mayer HM (1961) Chicago:Transportation and metropolitan planning. Papers and Proceedings of the Regional Science Association 7:241-247

Melamid A (1955) Some applications of Thuenen's model in regional analysis of economic growth. Papers and Proceedings of the Regional Science Association 1:133-138

Melamid A (1957) Regional aspects of economic development in multi-national states. Papers and Proceedings of the Regional Science Association 3:301-306

Morrill RL (1963) The distribution of migration distances. Papers and Proceedings of the Regional Science Association 11:75-84

Morrill RL (1965) Expansion of the urban fringe: A simulation experiment. Papers of the Regional Science Association 15:185-199

Nystuen JD, Dacey MF (1961) A graph theory interpretation of nodal regions. Papers and Proceedings of the Regional Science Association 7:29-42

Olsson G, Persson A (1964) The spacing of central places in Sweden. Papers of the Regional Science Association, European Congress, Lund 12:87-93

Philbrick AK (1957) Areal functional organization in regional geography. Papers and Proceedings of the Regional Science Association 3:87-98

Pitts FR (1963) Problems in computer simulation of diffusion. Papers and Proceedings of the Regional Science Association 11:111-119

Platt RS (1956) Discussion:The nature and scope of regional science. Papers and Proceedings of the Regional Science Association 2:46-47

Rodgers A (1955) Some aspects of industrial diversification in the United States. Papers and Proceedings of the Regional Science Association 1:31-46 
Rodgers A (1957) The role of the state in the industrial development of the port of Genoa, Italy. Papers and Proceedings of the Regional Science Association 3:290-300

Saushkin JG (1962) Large areal complexes of productive forces of the Soviet Union. Papers of the Regional Science Association, European Congress, The Hague 8:93-104

Smith TR (1957) Potential contributions of regional science to the field of geography. Papers and Proceedings of the Regional Science Association 3:13-23

Taaffe EJ (1959) Discussion:Regional employment and population forecasts via relative income potential models. Papers and Proceedings of the Regional Science Association 5:49-50

Thomas MD (1963) Regional economic growth and industrial development. Papers of the Regional Science Association, European Congress, Zurich 10:61-75

Thomas MD (1964) Resources and regional development-some comments. Papers of the Regional Science Association 13:201-205

Tobler WR (1965) Computation of the correspondence of geographical patterns. Papers of the Regional Science Association 15:131-139

Ullman EL (1958) Regional development and the geography of concentration. Papers and Proceedings of the Regional Science Association 4:179-198

Ullman EL, Dacey MF (1960) The minimum requirements approach to the urban economic base. Papers and Proceedings of the Regional Science Association 6:175-194

Warntz W (1957) Geography of prices and spatial interaction. Papers and Proceedings of the Regional Science Association 3:118-129

Wolpert J (1965) Behavioral aspects of the decision to migrate. Papers of the Regional Science Association 15:159-169

Wrobel A (1962) Regional analysis and the geographic concept of region. Papers of the Regional Science Association, European Congress, The Hague 8:37-41 